\title{
Judges and Lawmaking Authority: The New Brazilian Civil Procedure Code and the Limits of How a Civil Law Judge Could Act As a Common Law Judge
}

\author{
Rafael De Oliveira Rodrigues \\ Master in Law Candidate \\ Pontifícia Universidade Católica State attorney \\ São Paulo State, Brazil
}

\begin{abstract}
Resume
This article intends to compare two distinguished legal systems, by the perspective of the role of judges and how this officer of the court applies and interprets the law. This paper focuses on how and when judges are allowed to create the law within their judicial decisions. In this sense, we analyze how application and interpretation of the law fit within the legal concept of discretion and, in case of adopting the possibility in which the judicial authority carries out this prerogative. Also, it is taken into account how different judicial discretion comes from legislative and administrative discretion. By taking law application and interpretation as an exercise of judicial discretion is a key element to allow us to identify the way the judges create the law in civil law and common law systems. This reasoning will lead us to find elements to understand the purpose and length of a trend seen in countries in Latin America such as Brazil and its new Civil Procedure Code, which focuses on importing means from common law system to increase the efficiency of Judiciary Power, in order to attend social needs.
\end{abstract}

Keywords: Jurisdiction - lawmaking power - civil law - common law

\section{1-INTRODUCTION}

\subsection{JURISDICTION AND ITS CONNECTION TO THE LAW}

Before studying jurisdiction itself and its role in and for the state, it is elementary to reach a complete understanding of the subject, focused on the law and its function in society. For that goal, it is important to understand that the connection between society and law has existed for centuries and is understood by the lat in maxims: ubi societas ibi jus and ubi jus ibi societies. In this sense, by focusing sociability, it is one of the most important features in human race and it has been the fuel to carry out a complex and sophisticated society in which we exist. The necessity to look for fulfilling our needs using inter subjective relations has allowed us to reach many more issues that we could not be isolated.

So, this idea of society as a group of people gathered to help one another to fulfill the needs of their members was possible mostly because of the existence of an external element which has allowed the men to live together with some sense of organization. Thus, that key tool which has turned the life in society possible is recognized as the law. That being said, the law has created patterns and behavioral objective expectations, so that it made possible relationships among people. The inter subjective connections have developed in accordance to a determined form and pattern set by this external parameter. Along with been able to keep away the instability of illegitimate expectations from one side to the other.

However, despite the existence of law, it is relevant to point out that it is not void of the chance of dissatisfaction. According to ARAUJO CINTRA, GRINOVER and DINAMARCO: "the dissatisfaction is always an anti-social fact, independently of having the intended right. The undefinition of people situation is always a reason to anxiety and individual and social tension" From this quote, the authors affirm that the law itself creates mechanisms to resolve conflicts or as ARAUJO CINTRA, GRINOVER and DINAMARCO say, "social peacefulness". So, the law brings tools which would be used in such case of disobedience from any member of the society. In that sense, among several ways of enforcing the law, sweeping away conflicts among members of community, the most used tool around the globe is that in which the state holds so responsibility and duty of resolving social disputes. That public function is called jurisdiction. In relation to this mechanism (or instrument), it must be said that the history of human society has built a myriad of models but the most significant one, is the state jurisdiction. By this, it is acknowledged that the state holds the powers to set and implement laws, in such a way of resolving conflicts. It is important to consider that the origins of the expression, jurisdiction, come from the latin jurisdictio, which means, tells what the law is. 
According to this, the social peacefulness is acknowledged by the state as a very important value, so that it is an essential element to social development. By adopting such model, state jurisdiction, the state brings upon itself the duty of setting the applicable law to a case once presented to said authority as a conflict (in terms of interpretation or application of law).

Regardless of the model adopted (which will be considered only forward), jurisdiction is the duty which has been incorporated by the state because of the values in which it carries, which means, the social peacefulness and the law enforcement. Once adopting the state jurisdiction model, the conflict resolutions turn into a state manifestation of power. It is not, then, a simple accomplishment of its previously set, objective law (which seems to be), but a lawmaking act, surely respected, by the bounds which are provided by the system which gave it birth. In this sense, DERZI affirms "the sentence is an act of applying and creating law". ii Jurisdiction, then, not only to accomplish a precedent act of power but has itself authority to enact, by itself, acceptable social behavioral patterns.

With the premise jurisdiction is able to create law, it becomes necessary to consider the limits and the form in which this power is implemented by the authorities. By doing so, it is important to delve deeper into the study of the forms of states and types of law systems. That being said, the way state jurisdictions are implemented and their unique features and peculiarities, calls for more dialogue about the kinds of law systems that exist. This is one way to reach the depth of the lawmaking process of judges.

Thus, the common law system presents, prima facie, a lawmaking process considerably different from the civil law system. So being, by historical or philosophical reasons, the society of countries which common law is adopted acknowledges to judges the capacity of creating social behavioral norms. Another aspect sin countries where civil law is applied, the lawmaking process is bound by statutory law which judges are allowed to declare (by the means provided by the system) the sense and content of the rules already displayed in the statutory system. However, because of the challenges regarded to efficiency and legal certainty, there is a trend coming from Latin American countries to look more closely at the common law system. So, the present article intends to seek some limits for this trend, in order to better link the influence of the common law system to the basis of the civil law system.

\subsection{LAWMAKING POWER, LAW APPLICATION AND INTERPRETATION}

Before focusing on the role of the lawmaking process, it must distinguish it from other forms by which the judges apply jurisdiction. They are acknowledged by law interpretation and application. Countries which adopt the common law system or the civil law system present common features, i.e., a system full of determined values which give content to a normative basis. This normative basis is built by statutory rules, which is nothing more than symbols (words) that form, in theory, a system that target social norms. In this sense, to make it possible to implement this set of values and symbols, the proper authority must use tools, such as law interpretation and application (it is important mentioning law integration that, despite relevant, will not be considered on this paper). Thus, it is mandatory, in an appropriate moment, to link these means used by the authority in the lawmaking power. So, what is the meaning of law interpretation and what is the function?

The legal doctrine has been searching for some time a way to provide authorities boundaries to interpretation and the application of law. That being said, interpretation tends to frame the content, sense and length of the expressions which form law, providing it, as far as possible, with logic and symmetry. It is, as affirmed by SCHOUERI, "by interpretation, it would be possible to build a norm, drawing out the most powerful meaning of it". "iii In this sense, the law authority uses interpretative methods acknowledged by jurists to clarify the sense of expressions and signs which a simple subsumption to law is unable to do. Arguments have a reason whether this tool presents features of subjectivity or objectivity. Actually, the adoption of one way or the other depends on the focus of the interpretation process, i.e., on the interpretation building process (subjective) or, on the other hand, in the result of the operation (objective).

However, what seems to matter in relation to interpretative process is that its starting point is the statutes already in existence. In that order, the freedom of the interpreter is bound inside the parameters previously set by legislation. So being as, GRAU has affirmed that" the norm preexists in its sense, in stated in the text; the interpreter reveals it ${ }^{\text {iv }}$ Whether, from a preexistent law, the interpretation process could be a tool, as well, to implement the lawmaking process is a subject which will be considered further On the other hand, there is the application of law, i.e., a judicial phenomenon which makes the law (objective law) into the command that will rule out determined inter subjective relations. It is relevant to consider that the law application is, mainly, a mental process named subsumption, which intends to frame social facts analyzed inside the boundaries set by the legislation. To SCHOUERI, it seems the analysis over facts (made by the jurist) is called "qualification". By this procedure, it must take the most relevant elements from the facts and compare them to the abstract normative prescriptions.

Different from the interpretation process (which turns its eyes to the law, abstractly speaking, to give it some sense), the application divides its attention between abstract law and reality (facts, which it takes by the qualification). 
The law application, as well, (though not on the same intensity as law interpretation) has a connection to lawmaking power. In this sense, the jurists discuss whether or when a judge applies the law, they move forward and, in some cases, create law. With that, all the questions previously brought up will be considered in detail herein, so that this subject must be linked to each judicial system separately.

It is set in that way because the study of the possibility (and its length) of the lawmaking process depends on the features of jurisdiction and judicial system, as well as the way of seeing the law application and interpretation.

\section{Lawmaking Power In Civil Law System}

\subsection{BASIS OF THE SYSTEM}

Before focusing on the comments of the civil law system itself and its features, it is necessary, preliminarily, to give an ideological and philosophical analysis over the basis in which this judicial system has been built over history. With this goal, it is relevant to mention that this legal system has been conceived mainly in Continental Europe, where the first ideas had been sparked and then spread to many other countries throughout the world. In this sense, these countries, in response to the Dark Ages, started adopting a scientific process (which later was best known by Scientific Revolution), where the rationalism, or the pursuit of an abstract idea (pure reason) was the guided element that molded history. By Mister Rene Descartes $v$, among other important figures, gave us the possibility to see an ideology which tried to break the connection between knowledge and experience. It would be possible to reach to the right conclusion to most things, starting from an abstract idea and developing it, through a deductive process of reasoning.

Also, a historical context (especially in France) explains the idea of keeping the Judiciary Power apart from political decisions and the law, suggesting the statutory law (or the law created by the Legislative Power) as the only legitimate source of law. That being said, based on a positivistic conception of law, the civil law system acknowledges the statutory law (legislation) as the only authoritative way to produce law, setting behavior a norms to rule the society. In this sense, the assessment on the suitability of some social behaviors belongs to the legislative branch. So, only after a statutory law is adopted and signed into law, it tends to regulate all of society. The law, based on these ideas, is objectively abstract and subjectively general. It is important to mention, the civil law system (at least originally) provided with the statutory law the power to create, modify and extinguish any right whatsoever it may be and or belongs to. Thus, the judge has been put in a secondary role, out of the process. About this subject and because of the preeminent role provided in the legislation, the civil law system is a law model in which the legal positivism has found a broad range and at the beginning, along with the Exegese School, that subscribed the idea of a judge applying the law without self-interpretation. The judge would be (for the greatest minds of that time) the mouth which pronounces the law.

However, the School's rigid position which has been abandoned by some requires more flexibility. Some seek the theory of interpretation in getting relevant results. So, what was seen at first was that the only tool displayed by the judges to apply the law was the subsumption, in other words, the framing of facts brought to them to some legislation which (by itself) would bring some judicial consequences. As the theory of Interpretation has brought good results, since adopted, the judicial community has acknowledged that the authentic interpretation given by the legislator was not enough to apply the law sufficiently, to respond to social needs. Then, it provided to those whom applied the law some sort of tools which would allow them to assess the legislation in a considerably more efficient way in order to give a logical answer to society. For instance, systematic and teleological interpretation and analogy are huge examples of these tools.

In this sense, Elival da Silva Ramos, for whom:"Within the positivist thought, it didn't take long to the interpretation by simple reproduction or application of things already set inside the statutory law fall apart, acknowledging the creative vessel of jurisprudence. And whom did this in a unequivocal sense was nothing less than Hans Kelsen, perhaps the jurist whom the better symbolize the legal positivism, so as the wide acceptation of his work. So, the author of Pure Theory of law did critics against the thesis of automatic subsumption, when he said that "the idea brought by the traditional theory of interpretation, that the determination of an act could be reached by any kind of pre-existent law knowledge is a contradictory delusion, so as attempts the basis of the possibility of interpretation.

Kelsen, although demystifying the purely reproductive application of the law haven't had it to appreciate the role of the interpreter but to close him to legislator, keeping the questions about theory of interpretation and the use of juridical argument apart from Dogmatic". ${ }^{\text {vi }}$ However, as seen above, the classic legal positivism, which featured the civil law systems doesn't incentivize judicial discretion to allow the judges broad analysis of the content of law.

Despite this fact, it is inevitable the presence of this kind of discretion, providing the judge the chance of presenting himself to the legal system not just as an authority who just applies the law without participating in any degree ( with the decision taken by the state when the legislation was created). In that sense, we consider separately which is judicial discretion and which is administrative and legislative discretion. 


\subsection{AdMinisTrative, Legislative AND JUdiCIAL DisCRETION}

This subject is studied in the field of administrative law. Despite knowing there are some differences of perspective about the subject in Anglo-American and Continental European legal systems, considering the focus at this subtopic is on framing the subject on the civil law legal systems, legal discretion will be analyzed by the eyes of these countries. Administrative discretion is studied as a special power given to the public administrator to evaluate a practical situation and, based on opportunity and convenient criteria, make the best decision possible to defend the public interest. It must be considered that, this assessment and, as well as, this room for maneuvering is strictly under the statutory law, so that the public law demands on the public administrator a whole and complete obedience to statutes and their terms. That being said, the law provides, deliberately, this margin to the public administrator. It is acknowledged; in some cases statutes themselves deliberately are not sufficient to provide the state decision. On the other hand, with no need to state the obvious, state law doctrine provides discretion to the legislators as well, focusing to create new behavioral norms to guide society under the Constitution.

Although, legislative discretion is quite broader than that from the public administrator, so that they are not strictly bound by the existing statutory law. That is just the opposite. It is not rare for a new statute changing completely the existing patterns, i.e., any amendment attaches to said statute is intended to further clarify and improve it. It should be considered that legislative discretion (such as administrative and judicial) are not arbitrary and, we should make the distinction between these terms. Situations are presented in which the authority acts despite and goes beyond the law and its limits. Some are indifferent to any aspects of law. The relevant is just the public authority will. It is typical of absolutists kings who do not find any institutional checks and balances in any plan. The discretion, on the other hand, is limited to preset boundaries. The will, then, is bound to the law (mainly the Constitution and its values).

In this sense, for legislative discretion, the legislators, although not bound to pre-established legislation, are limited to the law mainly constitutional which provides them with authority over the statutes produced by them. So, the legislators can not conduct them with sole autonomy. In other words, they are bound mainly to the Constitution (in a formal and a material way).Although, having broad discretion, it is mandated by the law. Otherwise, it would be sole arbitrary. This being said, discretion is attributed by judicial authorities as well. On one hand, it is not possible for the Judiciary Power to rule based on convenience and opportune criteria, which shows the principal differences between the administrative and its. Judicial discretion is strictly connected to the statutory law, to the contrary from legislative discretion. The crucial point is, we do not recognize a limitless power which is given to a judge to innovate in law so that unconstitutional and the consequence of it which has not been considered as a case regularly ruled. Therefore, the judge must set aside the legislation only with just reason. So, they are unable to decide without considering the law in its entirety.

Relevant in this context shows how judicial discretion should be applied. At that point, it is presented by the use of methods of interpretation and law integration. Having already been considered, the legislator does not have the legal wherewithal to create legislation which would be able to foresee all the facts to societal rule, especially in these modern times, where it is becoming more and more complex. Besides, the statutes been displayed like symbols - words which necessarily need to be detoxified in a way to turn them from general orders (commands) into concrete ones that are able to fulfill the rule in society. With this, it is mandatory to adopt the sere sources (interpretation and integration law methods) mentioned above in a particular way to extract from these general commands the best sense of the word, i.e., the one in which best enforces the existent values set forth in the law, as well as the sense that put statutes in a better position inside the law system, doing so by a systematic analysis.

\subsection{Means Acknowledged Widening The Civil law System: Concepts, Types, General Clauses, Principles ANd Undetermined ConCePtS.}

Mentioned in the earlier topics, the focus was based on civil law judicial system. With that, by the legal positivist influence, statutes are the prevalent source of law. It is the legislation with the only authorized way to create societal behavioral patterns and shared administrative competences. With this, a judge is put in a secondary role, so to speak. From the beginning, the premise taken that the legal system is complete by itself, relegating the Judiciary Power to follow the statutes already set forth voiding any prejudices. However, the evolution of the theory of interpretation has led to a law system broadened by judicial influence in creating law patterns. It is clear to see, the model changing to adopta system in which does not recognize the statutory law as the only way to make law and, by doing so, with this been capable of resolving societal conflicts.

This idea provides a new concept of Montesquieu's separation of powers theory, upholding the integration of judges as political agents who actively participate in the process of creating patterns of societal behavioral. For that reason, the Legislative Power presents a dominant role, acknowledging the necessity for the presence of a more active Judiciary Power, in terms of creating law. In this sense, the legislator uses a group of legislative techniques, such as types, 
general clauses and undetermined judicial concepts which will allow the judges to perform in a positive way, complementing the sense of statutory law. In this sense, Misabel Derzi: Besides, this deeper comprehension of things, specially of the creative role of the judge, doesn't allow a "all-in", limitless, which bring to the ground the principle of separation of powers and, as well as, the public order and the rule of law. ${ }^{\text {vii }}$ It must not take the eyes off the idea in which the use of these tools must not be taken into account without seeing where it will be used. In this sense, the legislator must get the values around that segment of law and, by doing so, display the convenient instruments to reach the expected goal. For instance, Civil Law, especially Contract Law, in which the free will and business proposals are values substantially more intense than in Tax Law and or Criminal Law that, on the other hand, present substantial restrictions to fundamental rights, such as property and freedom. There is no such way to use those tools indistinctively, but in a way to get the goals set by each segment of law.

Important to be mentioned one of the greatest paperwork's about this subject, whose author, MISABEL DERZI affirms: Type is a descriptive abstraction of the reality, provided by the sense given by the Law. For that reason, it is considered the way of thought that, by its fullness in referential notes to the object, it is more concrete, determined and specific than an abstract concept. Where we find in law, types, it is given an opening - thought and wanted by the judicial system itself. This is in the case of contracts, comprehended by typical and atypical, in which the normative regulation, though rich in notes and features, accept other kinds of contracts, created in the daily law, in addiction too transitive forms, where the parties, respected the boundaries displayed by the system, mix up different notes between different species, with total approval of the law. ${ }^{\text {vii }}$ And following in her doctrine: The approach between types and reality and its richness in descriptive features puts it in between the individual and the conceptual abstract. ${ }^{\mathrm{ix}}$ The incorporation of the typological method of organization of thoughts (judicial thought), by nature and definition allows for a connection between abstract and real, is the acknowledgment of the normative abstract construction, since the absence of reality is not enough to provide the answers expected from the statutory law. There is the necessity of recognizing the importance and need for these tools which would allow a better link between these two worlds. On the other hand, general clauses are legislative ways put out, that, by their vagueness, bring to judicial system principles traditionally at first considered over judicial ${ }^{\mathrm{x}}$.

In this sense, for instance, the Brazilian Civil Code brings to the judicial system the principle of objective of good faith, both, to conclude and execute the contracts. This is the article 422 of the Code. In this case, the judicial system sets a metaphysical judicial concept which allows a broaden chance of participating in public duty which is to resolve conflicts evolving contracts and their interpretation. However, it is not enough to apply simple and automatic subsumption of the fact to the preset law. It demands a evaluative analysis, that would provide to a judge a more intensive role that they had as a simple law applicator. About principles, in brief, they are species of law which provides values to the judicial system. In that order, the positivism and its metaphysical conception of law in which the statutes is the only reliable source of law is considerably contested so that with this(for many people) it is seen as atheorical instrument to consolidate dictatorial regimes such as Nazism and Fascism in Continental Europe, as well as presented as an obstacle to take the members of those regimes to trial (for a positivist perspective, they were just following orders).

Hence, based on its ambiguity, a new doctrine was born. This new ideological way of seeing law provides its features not just to statutes but to principles as well, which, previously stated, carries on important values to the system and provides substance. In this case, an identification of these values, their suitability to facts as well as their length, especially when there would be a collision between principles and or their values, is a special role given to a judge. In the end, so by undetermined judicial concept it is understood to be opened to the legislators the intention of introducing into the judicial system vague and polygenic expressions (DERZI) ${ }^{\mathrm{xi}}$, targeting enclosing reality and abstract prescription. Then, for instance, whether the legislator prescribes the expression "urgency" or "non-wealthy person", it gives to a judge an increasing role where one will fulfill those expressions based on factual circumstances presented to them in a case.

\subsection{THE ROLE OF JURISPRUDENCE. STEADINESS}

Considering aforementioned arguments, it has been tested to demonstrate that the civil law system starts from a judicial model in which a judge presents a secondary role, just applying the law, heading to another paradigm that holds to him a political role, allowing to participate actively on the state decision making process.

In that sense, it has been tested to demonstrate that the own normative system, so that recognizing its capacity of giving effective answers to all social conflicts, brings on a myriad of tools which provide to ajudge broad judicial opinion. In that order, it has been set boundaries in which the judge would be limited into. Therefore, it is possible to affirm that the civil law system acknowledges the lawmaking authority of judges. The length or degrees, of course, depends on the particularities of each system, singularly considered. 
In general, there is no comparison with the lawmaking powers between judges and legislators, the latter being responsible for editing general and abstract rules, which means. Whereas with judges, judicial decision is considerably narrowed, since individual (with whom had taken part in a lawsuit) and are able to affirm a subjective right to someone. The public decision pronounced by the Judiciary Branch, set inside the limits of some lawsuit as well as within the frame displayed by the law, is considered legitime exercise of lawmaking power. However, the principle of legal certainty provides a higher complexity to the lawmaking authority of a judge (of the Judiciary Branch, better saying), so that it acknowledges the judicial decision, as a state act and within the limits set by the law. This creates legi time expectations of future social behaviors. Furthermore, the jurisprudence presented as a key element to create patterns of social confidence which must be observed. In this sense, an introductory idea about jurisprudence. For a civil law system, it is understood as a product of several decisions in the same sense, promoted by the same judge or Court. Based on the premise that these decisions are not just reproductions of pre-set normative content but, beyond that, an official decision which acts complementary to the statutes, it is prudent to conclude that, more than just a commitment to the case under analysis, there is a commitment to social behaviors in general (as well as the statutes).Thus, the repetition with steadily generate confidence with citizens to follow the sense (interpretation) taken by the State.

Additionally, there is one more way of authoritative lawmaking powers of judge which not only create the law in the sense which provide content to some legal norms or acts integrating the law by tools such as analogy, but make law in the sense in which this complementary act frames social behaviors in a desired sense. This been demonstrated, despite the statutory law is prevalent in the civil law system, which in turn increases the judge's role, since framed with the statutory boundaries in mind.

\section{Lawmaking power In Common Law System}

\subsection{BASIS OF THE SYSTEM}

Some countries have adopted a law system in which stated the habits, traditions and customs are vital elements and head the production and application of rules. Thus define common law system. This article does not intend to bring this topic into detail but set general guidelines which will allow us to define the necessary basis for its purpose and enable us a better understanding of the lawmaking process in such a system. Some points deserve attention in regards to this system. Firstly, it is not possible to define what common law is without mentioning Oliver Wendell Holmes Jr.'s definition, which is quoted from his book "The Common Law". He said that: A very common phenomenon, and one very familiar to the student of history, is this. The customs, beliefs, or needs of a primitive time establish a rule or a formula. In the course of centuries, the custom, belief or necessity disappears, but the rule remains. The reason which gave rise to the rule has been forgotten, and ingenious minds set themselves to inquire how it is to be accounted for. Some ground of policy is thought of, which seems to explain it and to reconcile it with the present state of things; and then the rule adapts itself to the new reasons which have been found for it, and enters on a new career. The old form receives a new content, and in time even the form modifies itself to fit the meaning which it has received. The subject under consideration illustrates this course of events very clearly. ${ }^{\mathrm{xii}}$ From his quote, there is a narrow connection between social practices and the law. In this sense, by repeating practices, where society consolidates its values and its understanding about what is right or wrong. A common law system strengthens an empiric perspective of seeing what is lawful. Therefore, the source of law is accepted as is by society (and implemented later by the state). This idea of law has been applicated for centuries and has reinforced by John Locke ${ }^{\text {xiii }}$ and David Hume ${ }^{\text {xiv }}$. Common law system is understood to be where the legal system is formed by repeated social actions throughout generations which are laden of values and principles to demonstrate the importance for the society for which deserves to be preserved by law. It is important consider that, sometimes, as affirmed by HOLMES Jr., habits or beliefs disappear, but not the social values which has come from them. Those values, in fact, give support to the law.

That being said: The law embodies the story of a nation's development through many centuries, and it cannot be dealt with as if it contained only the axioms and corollaries of a book of mathematics. In order to know what it is, we must know what it has been, and what it tends to become. Similarly, ROSCOE POUND, following the doctrine of Friedrich Savigny (who was an influential figure from the Historical School in Germany and known by his teachings about Volksgeist), stated that common law "is habits of popular action recognized by courts or from habits of judicial decisions or from traditional modes of judicial thinking, ${ }^{\mathrm{xv}}$.

Then, according to POUND, the customs could be presented under three different forms, which are: custom from popular action, from judicial decision and doctrine and academic discussion over principles. With that, it is possible to affirm that the full comprehension of common law demands the understanding of its two elements: tradition and enacted or imperative element. In this order, the historical understanding about the law and society for common law is a 
relevant element. But there is something else, so that the common law demands accurate analysis of how this historical element connects to law (subject that the Anglo-American judicial doctrine has been studying for centuries).

Then, under ananalytic perspective: for a long time they conceived that the traditional element had an independent validity beyond and without respect to the state. It is considered that the jurist, the judge or legislator simply gives these habits of action the dress of doctrine, precedent or statute. ${ }^{\mathrm{xvi}}$ Important to notice the intensity of this connection between tradition and the imperative element which makes it possible to understand what the lawmaking power of common law judges is, we must think about the way (means) in which the legal system provides judges the authority to apply the law.

For this reason, the specialized doctrine has been progressing throughout the centuries. At first, the common law system provided the judges the power to declare what law (common law) was. Although, after time the common law system evolved to demonstrate to them the power to create the law. Though, this discussion has come from centuries old theories, as it is possible to verify in the iconic Dr. Bonham's case, where Edward Coke, as the Chief Justice of the Court of Common Pleas set in 1610 that precedents should be submitted to common law.

All things considered, the precedent, such as the statutory rule, is able to not only acknowledge the principles already set by the common law and also, with the POUND words, "gives the dress of precedent". The same thought was brought by Blackstone in his Commentaries. As Justin Zaremby affirms in his Commentaries, Blackstone said that "the common law, if made in connection with certain natural principles, was fundamentally correct."xvii

However, jurists such as Bentham and Austin were pointed in affirming that by limiting the power of judges to such role of declaring the law which is already set minimizes said powers. With this, it is relevant to recognize power to create law by judges. Precedents, equally, is tradition in action. In other words, the law in action. In contrast, the ideological propositions which have been adopted by some countries, especially United States, such as legal realism and legal pragmatism uphold the idea of creating the law, so that the judge is not attached (just) to the past, but committed to the present and future.

The realism presents itself most significantly with HOLMES Jr. and his Metaphysical Group, followed by POUND and his sociological perspective over jurisprudence and, in the end, consolidates with Karl N. LLEVELYN, a Columbia University professor, mostly because of intense debate between the latter and POUND. In this sense, Llevelyn focused on law effectiveness and permanent societal changes: "and in flux typically faster than the law, so that the probability is always given that any portion of law needs reexamination to determine how far it fits the society it purports to serve" ${ }^{\text {,viii }}$ In that order, seen by the traditional perspective (declaratory) or by the perspective that provides to a judge a more active role (positivist), to common law, in theory, judges have more leeway in relation to civil law judges in terms of power to create law. The judicial discretion, then, is considerably wider. That being said, the common law system allows, in general, the co-existence between precedents and statutes, with the same capacity of establishing behavioral patterns and to dictate what law is. It means that, both have legal authorization to comprehend the values and principles of the society, based on a set of rules to be followed. It has been said in general so that whether decided to legislate, unless unconstitutional, the judicial interpretation must be framed by the limits of the statutes. In these terms, it is important to acknowledge the difference between these two systems. Within the civil law system, the judicial decision must be necessarily bound to the statutory law. That provides less judicial discretion in comparison to a common law judge, as detailed in the precedent topic. Therefore, as long as not limited by statutes, the common law legal system allows to judges a wide judicial discretion which finds its limits only on precedents, which means, the judicial decisions set by Superior Courts which bind the reasoning of lower Courts or singular judges.

\subsection{JUDICIAL DECISION ELEMENTS: RATIO DECIDENDI E OBITER DICTUM}

Though it seems just a technicality, the correct identification of the elements which form a precedent in common law is important so that it is the starting point to seek the length of a binding precedent. In this sense, considering the importance of the precedent in common law, it is necessary to look for its content and extensions. By doing so, Sir John Salmond affirmed this: A precedent, therefore, is a judicial decision which contains in itself a principle. The underlying principle which thus forms its authoritative element or often termed the ratio decidendi. The concrete decision is binding between the parties to it, but it is the abstract ratio decided which alone has the force of law as regard the world at large. xix $^{-1}$

The relevancy structure of a decision (considering it as a precedent), which includes two rules: in one instance the rule which will decide the case itself (it is restrained to the litigants) and on the other a rule which will overtake those and, in fact, will create law. The latter is known as ratio decidendi. Therefore, the study which features the binding content of a precedent, the doctrine, especially in United States, presents several models, in which Eugene Wambaugh, Arthur L. Goodhart and Rupert Cross are iconic. As for Wambaugh, the identification of ratio decidendi is given by looking 
for the legal reason in judgment (general rule) and test its fundamentals for deciding a case by setting aside one argument or another.

By doing so, it is possible to verify if the outcome of case would have been decided differently. In contrast, for Goodhart "the principle of a case is found by taking into account (a) the facts treated by the judge as material, and (b) his decision as based on them". And finally, the most consistent of the three, as Rupert Cross affirms the ratio decidendi should be verified by taking into consideration both material facts and the legal reasoning which leads to a final decision.

It is prudent to mention some words about obiter dictum. In this sense, the legal reasoning to reach a decision in many cases demands for previous judgments or presuppositions that, despite not being essential to uphold a final decision. Those arguments are considered "obiter dicta". Obiter dicta arguments, though could indicate the way of thinking of a judge in future cases are not able to bind other judges so that does not belong to the principle of the cause. With the precedent considerations, though seemingly purely theoretic and academic, allows us to identify the principles in cause, comprehended, acknowledged and applied by the judge in his task of creating the precedent. So, with the authority and binding force of precedents, the principle steps up to a new legal status, such as social behavioral patterns.

\section{THE INFLUENCE OF COMMON LAW SYSTEM ON CIVIL LAW SYSTEMS AND THE BACKLASH ON THE PRESENT SUBJECT}

As been set thus far, which sought to demonstrate general guidelines about both civil and common law systems, now it is time to verify whether in fact there is an influence on one or another. In that order, it is known that it is not new a trend in common law countries by increasing its legal system with statutory law (law made by the Legislative Power). However existing, not being the so goal of this work, the political, legal and social reasoning which led the countries to do so will be set aside. However, as expressed in this paper, there are countries which despite having adopted the civil law legal system, where the guideline is exclusively what the statutes set, are providing more and more authority to judicial decisions to do so. Therefore, from a system in which, in the beginning considered a judge as "the mouth that pronounce the words of law", they started taking into consideration why and how the law is created by the Courts. In this sense, at first the precedents have been entirely forgotten on the University benches. Moreover, they were not considered as arguments to convince public agents and their decision-making process (administrative or judicial). However, over time, changes occurred. The reason for this was the social assessment which had been shown to be the less efficient for the justice system. Then, in order to fix the unreasonable delays of the Judiciary Courts and the lack of legal certainty they have demanded a series of measures in regards to improving the justice service as a way to enforce the law. In that sense, a lot of research has been conducted and the results have shown a trend in several countries, especially in Latin America to take some judicial tools typical of common law legal system, in a way of bringing steadiness and agility to their judicial systems.

For instance, the World Justice Project, an independent and multidisciplinary organization created to help to implement the rule of law throughout the world, launches annually an Index, with the assessment of governmental institutions in 196 countries, in order to seek whether or not they obey standard rules of law acknowledged worldwide. It is possible for one to come away with the idea that among Latin American countries, such as Brazil, Colombia, Argentina, Mexico and Peru, it is a way of having a judicial system with considerably low levels of efficiency.

On the other hand, countries which have adopted the common law system, such as United States, United Kingdom, Australia, New Zealand or even South Africa have presented numbers much more convincing. Such results have suggested that by the high rates of efficiency in common law, civil law countries (especially in Latin America) have incorporated common law tools in order to bring steadiness and legal certainty to their systems. In order to provide lawmaking powers to their judges was one of these means. It is not the goal of this paper to consider whether this political decision (of incorporating common law means in order to improve the legal system) is good or not, so that it seems sociological. The focus here is whether is or not compatible to take, by civil law countries, common law means considering their features. To get into details, for instance, Brazil does not bring a different trend and has being grappling with this for decades. Its Supreme Court adopted, in 1963, the Summula, as a way to summarize its decisions in order to better apply them to the cases under judgment. After the consolidation of this procedure, Summula were adopted in all Courts in the country and jurisprudence started being taken into consideration as a tool to set the judicial thought.

The success of this idea was seen as a starting point to change the weight of jurisprudence in Brazilian's law. However, this changing obeyed the features of civil law, so that it was implemented not by tradition or customs but by statutes, which lifted the jurisprudence to another level. For example, the Constitutional Amendment 45, which acknowledged to the Supreme Court the competence to create Binding Summulas, or some ordinary laws, such as the new Civil Procedure Code which provided binding authority to Supreme Court or Superior Court of Justice precedents. The 
Brazilian Civil Procedure Code sets in its article 926 a duty of all Courts to keep their jurisprudence steady, straightforward and coherent. This norm shows the intention of the Brazilian law system of improving the jurisprudence in order to make it able to be applied to other cases.

Besides, the new code imposes to judges and Courts the duty of regarding the previous judicial decisions of the courts enlisted in the article 927, as the underlying reason to decide. Other example of this attempt of importing means from common lawis a rule which obliges judges to point out the facts and arguments by which they apply or not apply a precedent in discussion. As already pointed, there are substantial differences in terms of origins of this increasing of precedents between the studied legal systems. Common law has created it by tradition and civil law by statutes. Although, these facts have shown us the trend of admitting the power of creating the law, in a way of considering the precedent as a source of law, in order to set behavioral patterns. In this sense, the civil law system can't be considered a closed system (to other sources of law but the statutory) heading to be considered an open system, including the Judiciary Power in the relevant task of creating behavioral models. However, this opening process should be understood in the length and limits admitted by the civil law system and its basic features. That said, the authority of a precedent is given inside the boundaries admitted by the system to judicial discretion, which means, inside the frames in which the judgesare bound to interpret the lawsalready set by statutes (including, the most important one, Constitution).

\section{CONCLUSIONS}

The discretion of common law judges has been providing to them the powers to create law by precedents with the same authority as statutes. Thus, the judicial decision has the authority as the source of said law and, because of it, it is able to lay down rules. On the other hand, the discretion of civil law judges, in the way it is currently understood (which presents Brazil as an iconic example), the is being able to create precedents as well. Although, the length admitted by the system does not allow judges to rule as common law judges do. As previously considered, civil law system legislator has started using several instruments to improve the law in order to address social expectations, such as types, principles, general clauses and undetermined judicial concepts. However, by doing so, they turned the legislation into limits considerably flexible. In that sense, the judges present an important role, as public agents capable of fulfilling statutes and setting a legal system more suitable to societal environment. However, despite reaching that underlying purpose of law, in order to better attend social needs, this measure has caused another problem, so that there has not been judicial uniformity in how to interpret statutes. The consequence was legal systems which have lacked legal certainty and extremely inefficient so that the litigant was allowed freely to fill several appeals, including to Supreme and Superior Courts of Justice Taking that issue at stake, it is been seen a trend especially in Latin American countries which intend to solve the problem by taking means from common law legal systems in order to establish efficiency and legal certainty. One of these instruments is the precedents and their theory of how they are applied in common law. However, this political decision cannot be taken without any consideration. The suitability of such means must be analyzed priorly, considering the substantial differences among the basis and perspectives of the evolved legal systems. In that sense, it is not un know civil law judges are enabled to use the judicial discretion primarily by using the interpretative process in order to provide more effectiveness to statutory law. Under these limits, they are able to bind social activities and create behavioral standards for the purpose of bringing more legal certainty to the legal system. Therefore, judicial precedents in civil law legal system which is framed by statutes (mostly Constitution) are lawful as long as bound by preset statutes.

\section{Bibliografy}

ARAÚJO CINTRA, Antônio Carlos; DINAMARCO, Candido Rangel; GRINOVER, ada Pelegrini, Teoria Geral do Processo, Malheiros. 2010.

BECHO, Renato Lopes. Filosofia do Direito Tributário. Saraiva. 2009

Execução Fiscal: Análise crítica. Noeses. 2018

Lições de Direito Tributário. Saraiva. $3^{\mathrm{a}}$ edição

A Aplicação dos precedentes judiciais como caminho para a redução dos processos tributários, Rev. Fac. Direito UFMG, Belo Horizonte, n. 71, pp. 499 - 530, jul./dez. 2017 Precedentes e direito tributário: nova perspectiva da legalidade tributária, in: racionalização do sistema tributário, IBET

A aplicação da teoria dos precedentes e da decisão "per incuriam" em Processo Tributário,Revista Juris Plenum, v. 13, $\mathrm{n}^{\mathrm{o}} 78$, p. $141-152$, nov. 17

BINGHAM, Tom, The rule of law. Penguin Books.2010

CROSS, Rupert ; HARRIS, James W. Precedent in English law. 4 ed. Oxford: Claredon, 1991. 
DERZI, Misabel Abreu Machado, Modificações da jurisprudência no direito tributário: proteção da confiança, boa-fé objetiva e irretroatividade como limitações constitucionais ao poder judicial de tributar. Noeses. 2009

DINAMARCO, Cândido Rangel, Instituições de Direito Processual Civil, III, Malheiros. 6a edição. 2009.

DUXBURY, Neil, The nature and the authority of precedent, Cambridge.2008

FERRAZ Jr., Tercio Sampaio. Introdução ao Estudo do Direito. Atlas. $6^{\text {a }}$ edição. 2008

GOODHART, Arthur L., Determining the ratio decidendi of a case, Yale Law Journal XL, 161, 183 (1930)

HENRY HOME, Lord Kames, Principles of Equity, Knud Haakonsen, General Editor

HOLMES Jr., Oliver W., The Common Law,

LLEVELLYN, Karl N., Some realism about realism - responding to Dean Pound, 44 Harvard Law Review 1222, 1236 (1931)

POUND, Roscoe, Sources and Forms of Law, 21 Notre Dame Law Review 247 (1946).

RAMOS, Elival da Silva. Ativismo Judicial. Saraiva. 2010.

RAZ, Joseph, Between Authority and Interpretation

SCHOUERI, Luís Eduardo, Direito Tributário, Saraiva, $1^{a}$ edição, 2011

ZAREMBY, Justin, Legal Realism and American Law, Bloomsbury

${ }^{\text {i} A R A U ́ J O ~ C I N T R A, ~ A n t o ̂ n i o ~ C a r l o s ; ~ D I N A M A R C O, ~ C a n d i d o ~ R a n g e l ; ~ G R I N O V E R, ~ a d a ~ P e l e g r i n i, ~ T e o r i a ~ G e r a l ~ d o ~}$ Processo, Malheiros. 2010.

ii DERZI, Misabel Abreu Machado, Modificações da jurisprudência no direito tributário: proteção da confiança, boa-fé objetiva e irretroatividade como limitações constitucionais ao poder judicial de tributar. Noeses. 2009

iii SCHOUERI, Luís Eduardo, Direito Tributário, Saraiva, $1^{a}$ edição, 2011

${ }^{\text {iv }}$.GRAU, Eros Roberto, O direito posto e o direito pressuposto, Malheiros, $6^{\mathrm{a}}$ edição, 2005.

"René Descartes (1596 - 1650) - a French Philosopher best known by the statement "I think, therefore I am". Descartes proceeds to construct a system of knowledge, discarding perception as unreliable and, instead, admitting only deduction as a method.("Letter of the Author to the French Translator of the Principles of Philosophy serving for a preface" Translated by Veitch, John. Retrieved 6 Dec. 2011).

${ }^{\text {vi }}$ RAMOS, Elival da Silva. Ativismo Judicial. Saraiva. 2010.

Op. Cit., p. 123

${ }^{\text {ix }}$ Op. Cit., p. 125

${ }^{\mathrm{x}}$ OP. cit., p.159

${ }^{x i}$ Op. Cit., p. 145

${ }^{\text {xii }}$ HOLMES JR., Oliver Wendell, The Common Law.

xiii John Locke (1632-1704) - English philosopher considered one of the most significant thinkers of liberalism. A symbol of his ideas is presented in his "Essay concerning human understanding", 1690, where Locke affirmed that the knowledge comes already inside the human been and the task of philosophy would be just awaken it.

${ }^{\text {xiv }}$ David Hume (1711-1776) - Scottish philosopher best known for his empiricist philosophy. Best known by his "A treatise of human nature" (1739-40) and "An enquiry concerning human understanding" (1748), Hume set science and philosophy on new basis: to serve and understand the human nature.

${ }^{x v}$ POUND, Roscoe, Sources and Forms of Law, 21 Notre Dame Law Review 247 (1946).

${ }^{\text {xvi }}$ Op. cit.

xvii ZAREMBY, Justin, Legal Realism and American Law, Bloomsbury

xviii LLEVELLYN, Karl N., Some realism about realism - responding to Dean Pound, 44 Harvard Law Review 1222, 1236 (1931)

${ }^{\text {xix }}$ GOODHART, Arthur L., Determining the ratio decidendi of a case, Yale Law Journal XL, 161, 183 (1930) 